\title{
Thermal Analysis and Electrochemical Performance of Mn doped Cu Nano-ferrites
}

\author{
Amina I. Ghoneim ${ }^{1, *}$, Atsunori Matsuda ${ }^{2}$ \\ 1,* Physics Department, Faculty of Science, Tanta University, Tanta 31527, \\ Egypt \\ ${ }^{2}$ Department of Electrical and Electronic Information Engineering, \\ Toyohashi University of Technology, 1-1 Hibarigaoka, Tempaku-cho, \\ Toyohashi, Aichi 441-8580, Japan \\ *Correspondingauthor: mona_ghoneim@yahoo.com, \\ amina.ali@Science.tanta.edu.eg
}

MnxCu1-xLa0.12Fe1.88O4 Nano-spinels, $(x=0,0.25,0.5,0.75$ and 1) have been fabricated by co-precipitation strategy. XRD plots emphasized the complete emersion of the solitary-phase Nano-spinel for all the investigated Nano-powders. Nano-powders crystallite size $R$ declined with $x$. FTIR emphasized the emersion of Nano-spinel phase. DTA/TGA showed decline in samples' weight giving largest weight loss $\approx 22 \%$. Cycle voltammetry and charging/discharging inspection were done to scrutinize the electrochemical merits of MnLa0.12Fel.88O4 spinels in $1 \mathrm{M} \mathrm{KOH}$ electrolytic soln. MnLa0.12Fe1.88O4 Nano-spinels possess specified capacitance of $1500 \mathrm{mF} / \mathrm{g}$ at $50 \mathrm{mV} / \mathrm{s}$. The scrutiny illustrates a promising implementation of MnLa0.12Fe1.88O4 Nano-spinels as electrode nanocrystals for energy storage and sensing. Nyquist diagrams of MnLa0.12Fe1.88O4 Nano-spinels in frequency range appeared from 1.0 $\mathrm{Hz}$ to $20 \mathrm{kHz}$. MnLa0.12Fel.88O4 Nano-spinels retain low soln reluctance (Rs) as $12.9 \Omega$. 
Keywords: Structural Features; Thermal Analysis; Electrochemical Performance; Elastic Parameters; MnxCu1-xLa0.12Fe1.88O4 Nano-spinels.

\section{Introduction}

The present time research and investigation activity has been concentrated on the synthesis and fabrication of new structures and nanomaterials for a wide variety of utilizations as well as applications in miscellaneous vistas which are vital for human life approaches over earth planet. Obviously, fabrication and utilization of Nano-ferrites attracted much attention, since Nano-ferrites are advantageous in so many applications such as drug carriers in the form of hollow spheres, so that they can be used in drug delivery, as well as using them as heat element for anticancer magnetic hyper-thermic treating, so that offering them as useful candidates in medicine for multi-function magnetic carriers which can act both as cancerremoval as well as drug-delivery module [1]. Furthermore, their spreading implementations as informatory storage, humid environment and gas sensors, biomedicine, microwaving apparatus and communicating technological prospects $[1,2]$. Investigation on the new nanomaterials possess great impact scientifically and technically due to the surface and quantum confinementing impacts they possess that influence their nanostructure and chemical merits as an outcome. $\mathrm{Mn}$ Nano-ferrites possess great relevance for vital utilizations and numerous implementations, like recording media apparatus, ferro-fluid, biosensing, ... etc. Their chemical and structural merits vary with fabrication strategy, thermal heating, particle size, ions substitution, cation distribution amongst crystalline sites [1,2]. Moreover, Mn Nano-ferrites possess major concern imputing to their plentiful implementations including; biomedicine and electronic industries. $\mathrm{Mg}-$ Mn Nano-Spinel heated at diverse temperatures presented entertaining spectroscopic, electric and magnetic merits. It has been reported that such Nanospinels are convenient not only for academy approaches of structure and magnetic merits but also for technological vistas [1,2]. Regarding structural, physical and chemical merits of the Mn Nanoferrites, there emerges many environmental and 
technical applications and important daily expanding uses for these soft magnetic nanocrystals to be used in; like; miscellaneous types of catalysis, magnetic hyperthermia, antibacterial agents, water treatment modules, antenna rods, transducers, computer industry, multi-type sensors and RADAR systems [1,2].

In the present scrutiny $\mathrm{Mn}_{\mathrm{x}} \mathrm{Cu}_{1-\mathrm{x}} \mathrm{La}_{0.12} \mathrm{Fe}_{1.88} \mathrm{O}_{4},(\mathrm{x}=0,0.25,0.5,0.75$ and1) were fabricated utilizing co-precipitation strategy and scrutinized via Diffracting of X-rays (XRD), Furrier Transformed Infrared (FTIR), Thermal examination (DTA-TGA) and their electrochemical performance was scrutinized as well.

\section{Experimental Techniques}

\subsection{Preparation of MnxCu1-xLa0.12Fe1.8804 nanoparticles}

As-fabricated $\mathrm{Mn}_{x} \mathrm{Cu}_{1-\mathrm{x}} \mathrm{La}_{0.12} \mathrm{Fe}_{1.88} \mathrm{O}_{4},(\mathrm{x}=0,0.25,0.5,0.75$ and1) Nano-spinels have been fabricated using co-precipitation route according to the formula [3]:

$x \mathrm{MnCl}_{2} .4 \mathrm{H}_{2} \mathrm{O}+1-x \mathrm{CuCl}_{2}+0.12 \mathrm{La}\left(\mathrm{NO}_{3}\right)_{3} .6 \mathrm{H}_{2} \mathrm{O}+1.88 \mathrm{FeCl}_{3}+8 \mathrm{NaOH}$

$$
\mathrm{Mn}_{x} \mathrm{Cu}_{1-x} \mathrm{La}_{0.12} \mathrm{Fe}_{1.88} \mathrm{O}_{4}+(4.72+4 x) \mathrm{H}_{2} \mathrm{O}+8 \mathrm{NaCl}
$$

Detailed Procedure of Co-precipitation have already been reported by Amer, et al 2014 [4].

\subsection{Characterizations :}

Nano-ferrite powders were scrutinized via GNR APD 2000 Pro X-ray diffracting step scan sort and $\mathrm{CuK} \alpha 1$ radiation at wavelength $\lambda=1.540598 \AA$. X-rays' Diffracting methodology is a delicate route in order to characterize nanomaterials as well as scrutinizing the internal structure of nanocrystals. It is utilized for affirming the crystalline structure simply and precisely. In other words without X-rays' diffracting methodology the crystalline structure is unknown totally. Lattice cons a was contrived exploiting the expression; $\mathrm{a}=\mathrm{d}$ (h2 
$+\mathrm{k} 2+12) 1 / 2$, whilst $\mathrm{d}$ is the inter-planar widening elicited by exploiting Bragg's formula; $2 \mathrm{~d} \sin \theta=\mathrm{n} \lambda$, and $\theta$ is Bragg's angular position [5]. FT-IR is the secondary easy way for distinguishing nanomaterials simply and precisely as well. FT-IR spectral plots were explored via Bruker-Tensor-27-FT-IR - type Spectrometer in the range from 200 to $4000 \mathrm{~cm}-1$, at ambient temperature. Force cons F1 and F2 for A- and B-sites were contrived using the formula; $\mathrm{Fc}=$ $4 \pi 2 \mathrm{C} 2 \nu 2 \mu$, where $\mathrm{C}$ is light rapidity, $\nu$ is the vibration frequency and $\mu$ is the reduced mass of ions, $\mu \approx 2.061 \times 10-23 \mathrm{gm}[6,7]$.

DTA/TGA is the highly precise route for thermic analysis and examining the transforming inside nanomaterials. TGA and DTA of Nano-spinels were performed in N2-atmosphere via Perkin-Elmer STA 6000 thermic examination module at heating rate of $15^{\circ} \mathrm{C} / \mathrm{min}$.

\subsection{Electrochemical Performance measurements:}

Electrochemical Performance was performed via 3-electrode cell module using a Solartron SI 1286 electrochemical workstation in $1 \mathrm{M} \mathrm{KOH}$ electrolytic soln at ambient temp. Working electrode was adjusted by mix of $\mathrm{MnLa}_{0.12} \mathrm{Fe}_{1.88} \mathrm{O}_{4}$ Nanospinels into soln of isopropyl alcohol, $\mathrm{H} 2 \mathrm{O}$ and nafion (volume ratio 5:5:0.1) with aid of ultra-sonication $(10 \mathrm{~min})$ to form homogeneous soln. Taking from premixed soln, $10 \mu \mathrm{L}$ amount of liquid was dropped on glassy carbon electrode (GCE) (3 mm diameter) and liquid evaporated in air to dry active materials. In 3electrode measurement, $\mathrm{MnLa}_{0.12} \mathrm{Fe}_{1.88} \mathrm{O}_{4}$ Nano-spinels, platinum (Pt) wire and $\mathrm{Hg} / \mathrm{HgO}$ works as working electrode, counter electrode and reference electrode, respectively. Cycle voltammetry (CV) and Galvano-static charging/discharging measures were performed to examine electrochemical performance of $\mathrm{MnLa}_{0.12} \mathrm{Fe}_{1.88} \mathrm{O}_{4}$ Nano-spinels electrode for super-capacitance SCs implementations [8]. 


\section{Results and discussion}

\subsection{X-ray diffracting plots (XRD)}

XRD plots in Fig. 1 for $\mathrm{Mn}_{x} \mathrm{Cu}_{1-x} \mathrm{La}_{0.12} \mathrm{Fe}_{1.88} \mathrm{O}_{4},(x=\mathbf{0}, \mathbf{0 . 2 5}, \mathbf{0 . 5}, 0.75$ and 1) nanocrystals verified egress of Nano-spinels' monocular-phase; affirmed by JCPDS cards no. 00-001-1121. The protruded Supremes at the planes $(220,311$, $222,400,422,511,440)$ exquisitely affirming the spinel structure. Plainly, for ultra-small nano-regime merit of those Nano-spinels so that emerges wider XRD summits in Fig. 1, also asserted regarding their nano-regime crystallite sizes as illuminated in Fig. 2. It is observed that; Lattice constant a declined with x [9]. Elucidated crystallite size $\mathrm{R}$ declined with $\mathrm{x}$ imputing to the permutation process and it lies in Nano-scale ambit [10].

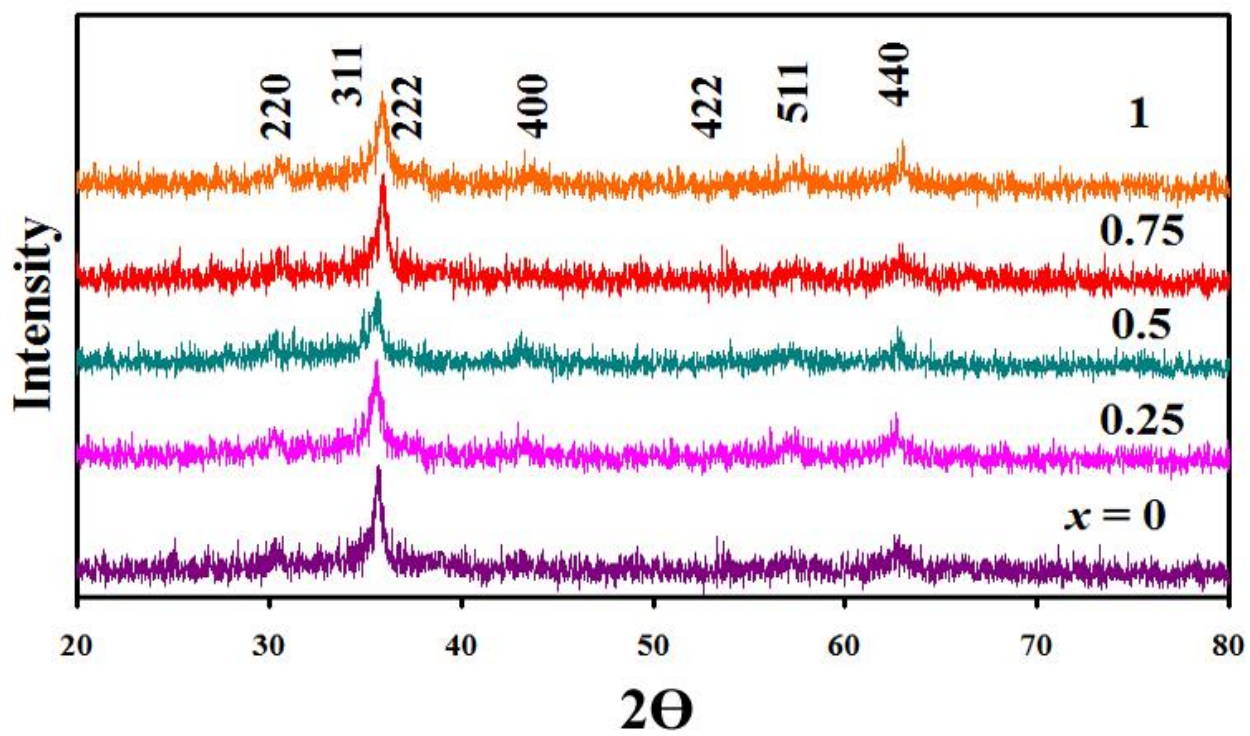

Fig. 1 XRD plots of As-Prepared $\mathrm{Mn}_{x} \mathrm{Cu}_{1-x} \mathrm{La}_{0.12} \mathrm{Fe}_{1.88} \mathrm{O}_{4}$ nanocrystals.

Crystallite size declined with Mn content x, see Fig. 2, assigning to the permutation condition of smaller ionic radios of $\mathrm{Mn} 2+(0.81 \AA)$ instead of larger $\mathrm{Cu} 2+(0.87 \AA)$. Actually, the specified Surface area S illuminates reliance on the 
delicate crystallite's size $\mathrm{R}$ and elucidated $\mathrm{X}$-ray density $\mathrm{Dx}$, whilst strain $\varepsilon$ depends on R. Since, Nano-spinels possess smaller crystallite's sizes, so, they possess larger specified surface areas [11]. S and $\varepsilon$ demeanours are illuminated in Fig. $2[12,13]$.
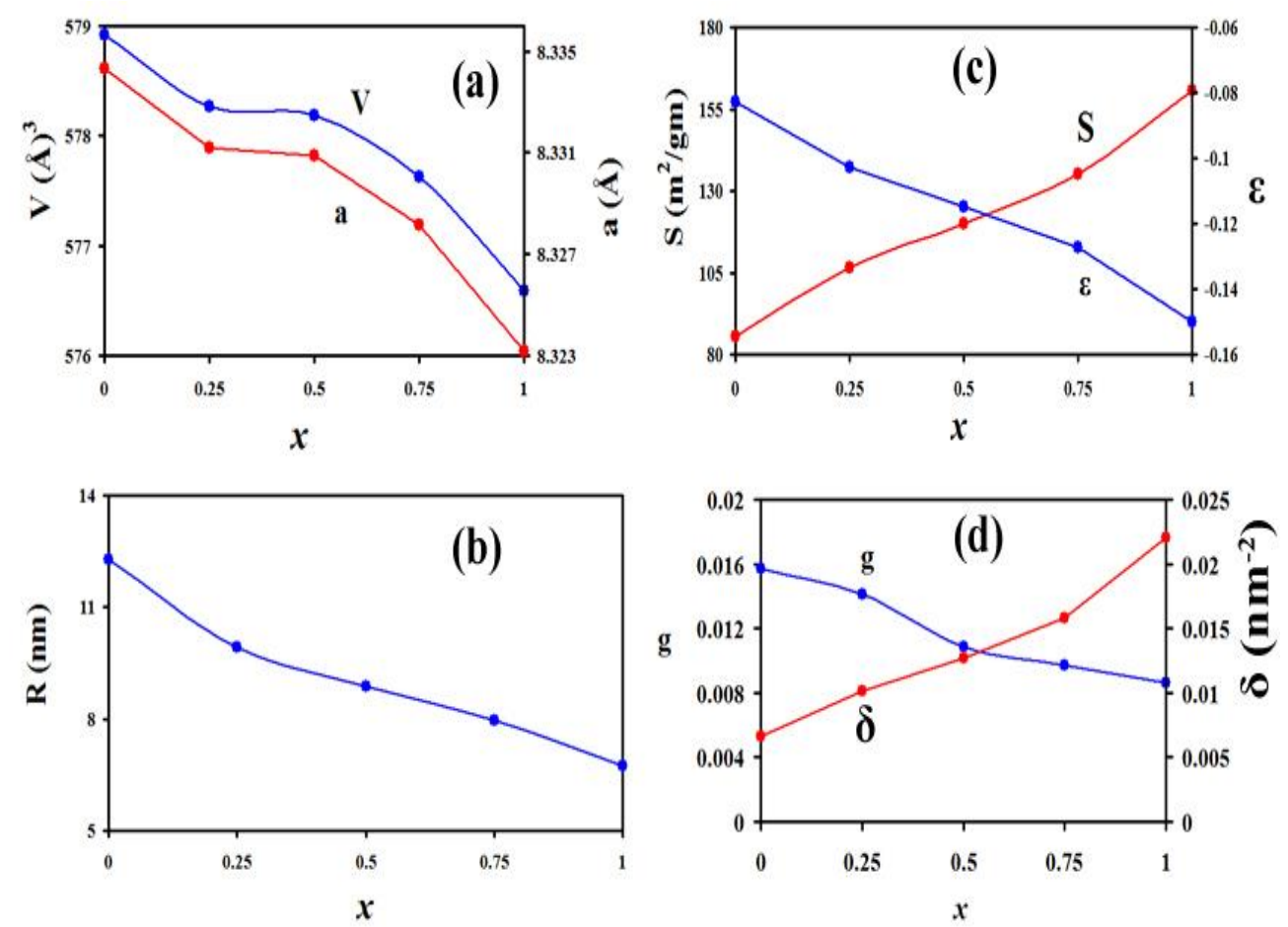

Fig. 2 (a) Lattice constant a and unit cell volume versus Mn content $x$, (b)

Dependence of the crystallite size $\mathrm{R}(\mathrm{nm})$ on $x$, (c) Reliance of the specific surface area $\mathrm{S}$ and strain $\varepsilon$ on $\mathrm{x}$ and (d) Variation of distortion parameter $\mathrm{g}$ and dislocation density $\delta$ with $x$.

X-ray density was well concluded utilizing the formula [13]:

$$
D_{X}=\frac{Z M}{N_{A} V}
$$

, $\mathrm{Z}$ is molecules no. per unit cell $(\mathrm{Z}=8)$; $\mathrm{M}$ is the molecule's mass and NA is Avogadro's no. 
In order to conclude the elucidated porosity $(\mathrm{P})$ the following formula is valid [4]:

$$
P=1-\frac{D}{D_{x}}
$$

, D and Dx are bulk and theoretical (X-ray) densities, by order.

Demeanour of bulky density D, contrived theoretic density Dx and porosity $\mathrm{P}$ with $\mathrm{x}$ is illuminated in Fig. 3. Precisely, Dx and D gradually decrease with the surge of Mn2+ content $\mathrm{x}$, while $\mathrm{P}$ surges. Decrease in Dx and D is imputed to permutation of lighter atomic weight $\mathrm{Mn}^{2+}$ ions (54.938) instead of heavier $\mathrm{Cu}^{2+}$ ions (63.546).

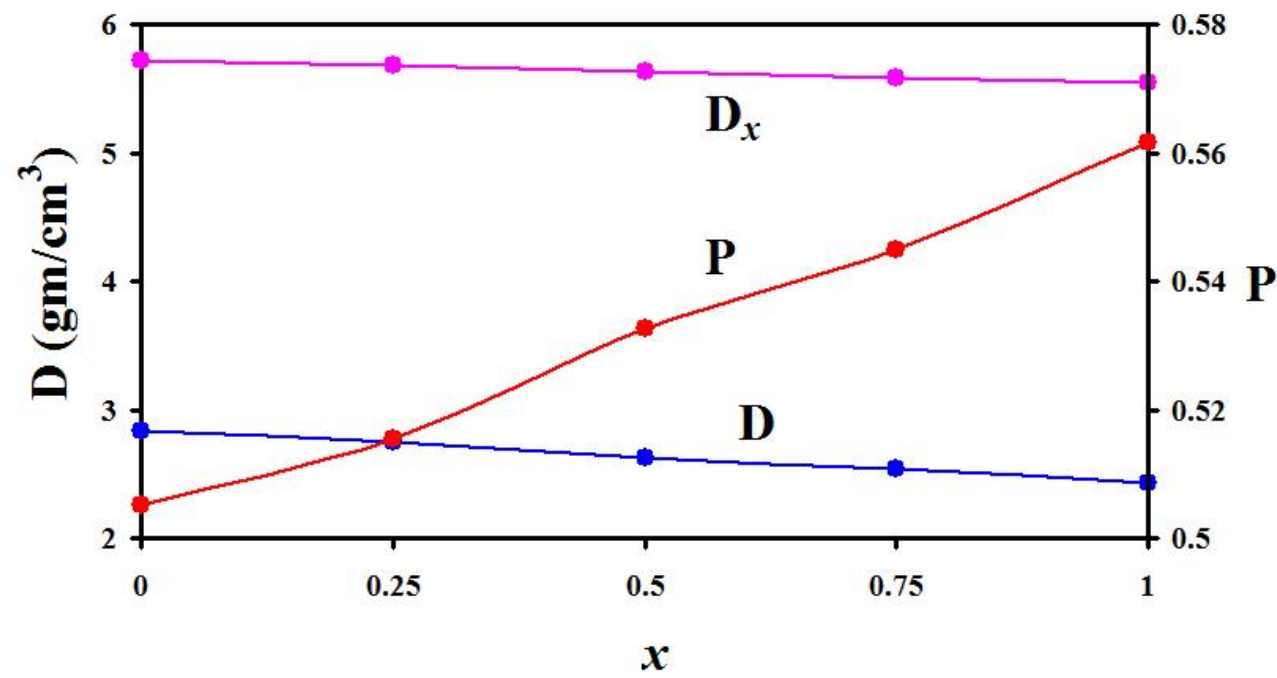

Fig. 3 Variation of the bulk density $\mathbf{D}$, theoretical density $\mathbf{D}_{x}$, and porosity $\mathbf{P}$ with $\boldsymbol{x}$.

\subsection{Structural Phase Analysis}

Dimensional unit-cell volumes $\mathrm{V}$ for these Nano-regime samples were contrived utilizing the formula [14];

$V_{\text {cell }}=a^{3}$. Dimensional cell volume $\mathrm{V}$ declines with $\mathrm{x}$ imputing to the permutation process, as illuminated in Fig. 2-a. 
The inter-chain distance $r$ could be formulated via the relations [12]:

$$
r=\frac{5 \lambda}{8 \sin \theta}
$$

In addition to this, Dislocation density $\delta$ was contrived utilizing the expression $[12,15]$ :

$$
\delta=\frac{1}{R^{2}}
$$

; $\mathrm{R}$ is crystallites sizes.

Distortion parameter $g$ was contrived via the formulation $[12,15]$ :

$$
\mathrm{g}=\frac{\frac{\beta_{1 / 2}}{\tan \theta}}{\tan }
$$

Fig. 2-d discloses reliance of $\mathrm{g}$ and $\delta$ on $\mathrm{R}$ and $\theta$, whilst $\mathrm{g}$ and $\delta$ rely on interior amendments in Nanocrystal's lattice spacing and oxygen ion concentration [15]. Specified surface area S of Nano-spinels contrived via the formulation [11];

$$
S=\frac{6000}{R_{X R D} D_{x}}
$$

Strain $\varepsilon$ of Nano-spinels contrived via the formulation [11];

$$
\beta_{1 / 2} \cos \theta=\frac{0.94 \lambda}{R_{X R D}}+4 \varepsilon \sin \theta
$$

Strain $\varepsilon$ interior these Nano-spinels counts on cations type and their crystallographic configuration, (see Fig. 2-c), as well as the protruded crystalline anisotropy [16]. Whilst, specified surface area $\mathrm{S}$ revealed a high evaluation surging with $\mathrm{x}$, assigning to the Nano-regime of R, (see Fig. 2-b and c). 
Table 1 The inter-chain distance $r$, error $= \pm 0.02$.

\begin{tabular}{|c|c|}
\hline \hline $\boldsymbol{x}$ & $\mathbf{r}$ \\
\hline 0 & 3.141 \\
\hline 0.25 & 3.149 \\
\hline 0.5 & 3.148 \\
\hline 0.75 & 3.122 \\
\hline 1 & 3.123 \\
\hline \hline
\end{tabular}

\subsection{FT-IR Spectral plots}

FT-IR diagrams for $\mathrm{Mn}_{x} \mathrm{Cu}_{1-x} \mathrm{La}_{0.12} \mathrm{Fe}_{1.88} \mathrm{O}_{4},(x=0,0.25,0.5,0.75$ and 1) nanocrystals registered in between 200 and $4000 \mathrm{~cm}-1$ are illuminated in Fig. 4. Protruded vibrational summits of IR are illuminated in Table 2. Six oscillation summits of $v 1, v 2, v 4, v A, v B$ and $v$ T protruded in FT-IR spectral diagrams. $v 1$ around $\sim 615.28 \mathrm{~cm}-1$ and $v 2$ around $\sim 443.62 \mathrm{~cm}-1$, (Table 2), referred to substantial sprawl oscillations of A-occupational allocations ligations; whereas enormous recapture strengths for bond-bending oscillations subsist on Boccupational allocations [17]. Predominately, affirmation of emersion of Nanospinel configuration is affirmed by the entity of both $v 1$ and $v 2$. Likewise, it was monitored that vibrational summit around $231.45 \mathrm{~cm}-1$ for $v 4$ referring to lattice oscillations of Nano-Spinel configuration and it relies on lumps of entirety of Aoccupational allocations divalent cations and their ligaments, $\mathrm{Fe}^{2+}-\mathrm{O}^{2-}, \mathrm{Mn}^{2+}-$ $\mathrm{O}^{2-}$ and/or $\mathrm{Cu}^{2+}-\mathrm{O}^{2-}[4,18]$. Ternary vibrational summit $v \mathrm{~T}$ was unfolded around $\sim 1641.38 \mathrm{~cm}-1$ imputing to the retained H2O in Nano-Crystals [19]. Vibrational summits around 883.38 and $1082.04 \mathrm{~cm}-1$, respectively are referring to vibrational summits $v \mathrm{~A}$ and $v \mathrm{~B}$. Vibrational summit $v \mathrm{~A}$ refer to the coexistence of $\mathrm{Fe}^{2+}, \mathrm{Mn}^{2+}$ amongst the A- sites. Vibrational summit $v \mathrm{~B}$ refer to coexistence of $\mathrm{Fe}^{4+}-\mathrm{O}^{2-}$ and $\mathrm{Cu}^{2+}-\mathrm{O}^{2-}$ cations. Protrude of $\mathrm{Fe}^{4+}$ cations impute to electronical jumping in-between $\mathrm{Fe}^{3+}$ and $\mathrm{Mn}^{2+}$ cations [4]. These split are distinguishing of 
the Jahn Teller effect (JTE). It is clear that, the sharp surge of $v B$ intensity impute to the distortion of JTE of $\mathrm{Cu}^{2+}$ ions which distorts the metal-oxygen bonding.

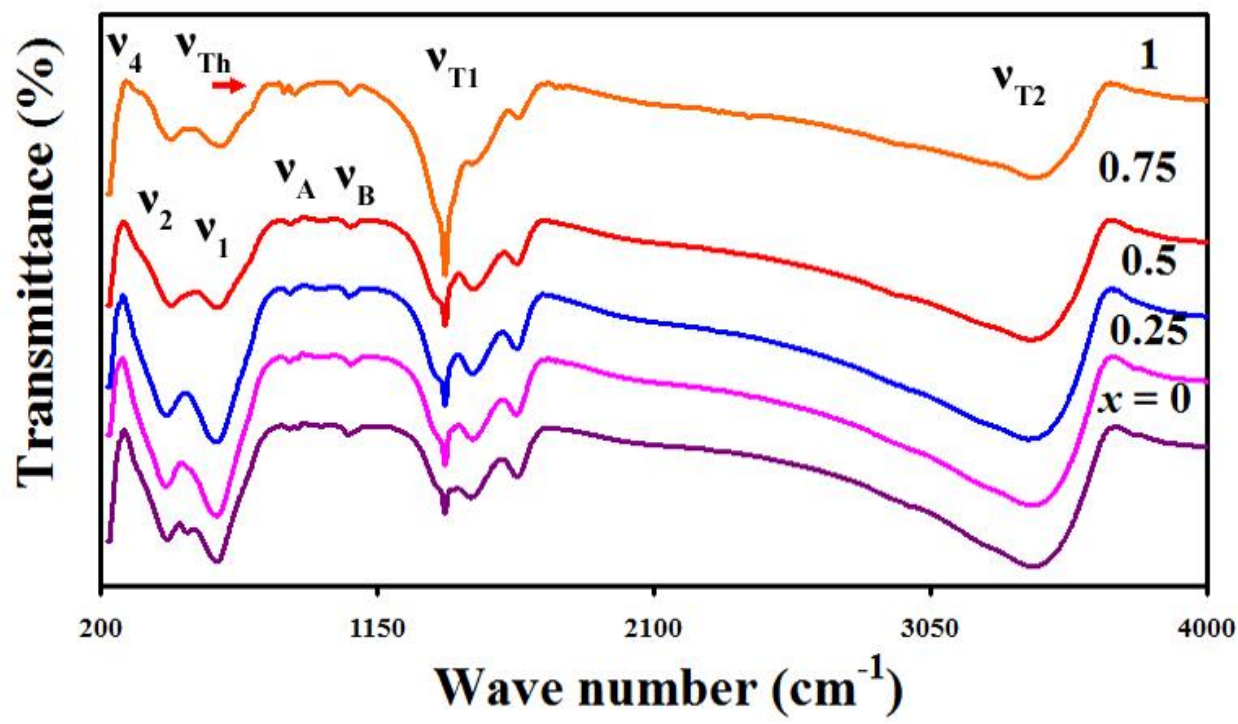

Fig. 4 FT-IR spectral plots of As-Prepared $\mathrm{Mn}_{x} \mathrm{Cu}_{1-x} \mathrm{La}_{0.12} \mathrm{Fe}_{1.88} \mathrm{O}_{4},(x=\mathbf{0}, \mathbf{0 . 2 5}$, $0.5,0.75$ and 1) nanoparticles.

Table 2 FT-IR vibrational summits positions $v_{n} ; n=1,2, \ldots$ and B, Threshold frequency $v_{T h}$, Threshold energy $E_{T h}(\mathrm{eV})$, Force con $\mathrm{F}_{1}$ and $\mathrm{F}_{2}$, error $=$ \pm 0.02 .

\begin{tabular}{|c|c|c|c|c|c|c|c|c|c|}
\hline $\boldsymbol{x}$ & $\left(\begin{array}{c}v_{1} \\
\left(\mathrm{~cm}^{-1}\right)\end{array}\right.$ & $\begin{array}{c}v_{2} \\
\left(\mathrm{~cm}^{-1}\right)\end{array}$ & $\begin{array}{c}v_{4} \\
\left(\mathrm{~cm}^{-1}\right)\end{array}$ & $\begin{array}{c}v_{\mathrm{A}} \\
\left(\mathrm{cm}^{-1}\right)\end{array}$ & $\begin{array}{c}\mathbf{v}_{\mathbf{B}} \\
\left(\mathrm{cm}^{-1}\right)\end{array}$ & $\begin{array}{c}v_{\mathrm{Th}} \\
\left(\mathrm{cm}^{-1}\right)\end{array}$ & $\begin{array}{r}\mathbf{E}_{\mathrm{Th}} \\
(\mathrm{eV})\end{array}$ & $\begin{array}{c}\text { F1 } \\
* 10^{\wedge} 5 \\
\text { (Dyne } \\
\text { /cm) }\end{array}$ & $\begin{array}{c}\mathbf{F 2} \\
* 10^{\wedge} \\
5 \\
\text { (Dyne } \\
\text { /cm) }\end{array}$ \\
\hline 0 & 615.28 & 443.62 & 231.45 & 883.38 & $\begin{array}{c}1082.0 \\
4\end{array}$ & 827.44 & 0.103 & 2.77 & 1.44 \\
\hline 0.25 & 613.35 & 439.76 & 231.45 & 869.87 & $\begin{array}{c}1070.4 \\
6\end{array}$ & 810.08 & 0.101 & 2.75 & 1.42 \\
\hline 0.5 & 609.49 & 437.83 & 233.38 & 866.02 & $\begin{array}{c}1070.4 \\
6 \\
\end{array}$ & 800.44 & 0.099 & 2.72 & 1.40 \\
\hline 0.75 & 619.13 & 462.91 & 231.45 & 867.95 & $\begin{array}{c}1074.3 \\
2\end{array}$ & 796.58 & 0.098 & 2.81 & 1.57 \\
\hline 1 & 634.56 & 457.12 & 231.45 & 879.52 & $\begin{array}{c}1072.3 \\
9\end{array}$ & 781.15 & 0.097 & 2.95 & 1.53 \\
\hline
\end{tabular}


Precisely, free or absorbed $\mathrm{H}_{2} \mathrm{O}$ on $\mathrm{Mn}_{x} \mathrm{Cu}_{1-x} \mathbf{L a}_{\mathbf{0 . 1 2}} \mathbf{F e}_{1.88} \mathbf{O}_{4},(x=\mathbf{0 , 0 . 2 5}$, 0.5, 0.75 and 1) nanocrystals gives rise to two vibrational summits around 3435.1 $\mathrm{cm}^{-1}$ vicinity as well as one summit around $\sim 1641.38 \mathrm{~cm}^{-1}$. The intensive summit around $\sim 3435.1 \mathrm{~cm}^{-1}$ may be assigned to the stretching vibrational status of $\mathrm{H}-\mathrm{O}-$ $\mathrm{H}$ vibrations, also to $\mathrm{H}_{2} \mathrm{O}$ traces [20,21]. Ternary vibrational summit $v_{\mathrm{T}}$ was unfolded around $\sim 1641.38 \mathrm{~cm}^{-1}$ and the summit around $1500 \mathrm{~cm}^{-1}$ which were imputed to $\mathrm{H}_{2} \mathrm{O}$ in $\mathbf{M n}_{x} \mathbf{C u}_{\mathbf{1 - x}} \mathbf{L} \mathbf{a}_{\mathbf{0 . 1 2}} \mathbf{F e}_{\mathbf{1 . 8 8}} \mathbf{O}_{\mathbf{4}}$ nanoparticles [3,13]. Nonlinear $\mathrm{H}_{2} \mathrm{O}$ molecule has substantial oscillational status: symmetric, asymmetric stretching and scissoring oscillation status [12].

Debye temperature $\theta_{D}$ is precisely distinguished as the temperature at which nanocrystal has its highest normal summit of vibration. Debye temperature assigns the nanocrystal's lattice stability. When the nanocrystal is heated below Debye temperature, the atomic motion is restricted, and the electrons move across the lattice planes with minimal scattering. But above Debye temperature, the scattering becomes quite large. So materials with higher Debye temperature have low scattering and hence become more stable.

Debye temperature was concluded via the formulation [22-25]:

$$
\theta_{D}=\frac{\hbar C v_{a v}}{k}=1.438 v_{a v} \quad \text { and } \quad v_{A V}=\frac{v_{1}+v_{2}}{2}
$$

, $v_{a v}$ is the mean value of wave no's of vibrational summits, $\hbar=h / 2 \pi, h$ is the Plank's constant, $\mathrm{k}$ is Boltzmann's constant, $\mathrm{C}=3 \times 10^{10} \mathrm{~cm} / \mathrm{s} ; \mathrm{C}$ is light rapidity and $\hbar C / k=1.438$ for Nano-spinels [22-25]: $\theta_{D}$ nearly $\approx 761.35 \mathrm{~K}$ and impressed by wave no.'s of IR vibrational summits.

Concerning specified thermic theorem; the egress of conduction electrons' portion (n-type transporters) which essentially procure somewhat of thermic potency declining its saucepan, and this bolsters connotation that conducting process may 
impute to electrons, and vice versa. Sill thresholding frequency $v_{T h}$ is protruding around $827.44 \mathrm{~cm}^{-1}$ owing to the transition electrons, while $v_{T h}$ can be egressed from supreme spot of FT-IR spectral plots [22-25]; thence, conduction electron no's possess influence on $v_{T h}$ and $\theta_{\mathrm{D}}$. The estimation of force cons $\mathrm{F}_{1}$ and $\mathrm{F}_{2}$ for A- and B-occupational allocations asserted reliance of $F_{1}$ and $F_{2}$ on oscillational frequencies at these allocations, (Table 2).

Substantially, Threshold energy was concluded via the expression [7]:

$$
E_{T h}=h C v_{T h}
$$

, $\mathrm{h}$ is Plank's constant, $\mathrm{C}=3 \times 10^{10} \mathrm{~cm} / \mathrm{s}$; $\mathrm{C}$ is light rapidity, $v_{T h}$ is the threshold frequency. Estimation of $v_{T h}$ and $E_{T h}$ are illuminated in Table 2.

Threshold vibrational summit $v_{T h}$ egressed around $827.44 \mathrm{~cm}^{-1}$ shifting towards lower frequencies imputing to the concentration of $\mathrm{Fe}^{2+}$ and $\mathrm{Fe}^{3+}$ and as well assigning to the hopping between $\mathrm{Fe}^{2+}, \mathrm{Fe}^{3+}$ and $\mathrm{Fe}^{4+}$ cations as illuminated in the following expression:

$$
\mathrm{Fe}^{2+}+\mathrm{Fe}^{4+} \leftrightarrow \mathrm{Fe}^{3+}
$$

Thence, threshold energy $E_{T h}$ have lower evaluation directly on the same demeanour as that of $v_{T h}$ directly depending on the estimation of $v_{T h}$, in other words; as $v_{T h}$ declines, the threshold energy declines as well (Table 2).

Table 3 : Debye Temperature $\Theta_{D}$, Poison ratio $|\sigma|$, Stiffness constant $C_{11}$ and $C_{12}$, error $= \pm 0.02$.

\begin{tabular}{|c|c|c|c|c|}
\hline \hline $\boldsymbol{x}$ & $\begin{array}{c}\boldsymbol{\Theta}_{\mathbf{D}} \\
(\mathbf{K})\end{array}$ & $|\boldsymbol{\sigma}|$ & $\mathbf{C}_{\mathbf{1 1}}$ & $\mathbf{C}_{\mathbf{1 2}}$ \\
\hline 0 & 761.35 & 0.203 & 366.27 & 93.17 \\
\hline 0.25 & 757.19 & 0.214 & 387.52 & 105.24 \\
\hline 0.5 & 753.02 & 0.232 & 373.87 & 112.59 \\
\hline 0.75 & 777.99 & 0.244 & 390.68 & 126.38 \\
\hline 1 & 784.92 & 0.262 & 396.21 & 140.46 \\
\hline \hline
\end{tabular}




\subsection{Elastic properties}

Elastic cons illuminate the merits of the binding forces and the thermal features of solids. Particularly, Young's modulus of Nano-spinels is a vital agent for various magnetic core styles such as rods and rings.

For scrutinizing the elastic merits of these nanomaterials, stiffness cons $\mathrm{C}_{11}$ and $\mathrm{C}_{12}$ are concluded from the formulations; [24,25]:

$$
C_{11}=\frac{F}{a} \quad \& \quad C_{12}=\frac{C_{11} \sigma}{(1-\sigma)}
$$

, $F$ is average force cons concluded via [12]; $F=\left(F_{1}+F_{2}\right) / 2$ and $\sigma$ is Poisson's ratio $[\sigma=0.324(1-1.043 \mathrm{P})]$, $\mathrm{P}$ is the porosity $[24,25]$. Estimations of $\sigma$ lie in between $0.2-0.26$ (Table 3), which lie in between -1 to 0.5 in perfect matching with the isotropic elasticity theory $[24,25]$. Table 3 illustrates that $C_{11}$ and $C_{12}$ possess irregular increase with $\boldsymbol{x} . \mathrm{C}_{11}$ and $\mathrm{C}_{12}$ small rise may point to losing the retained $\mathrm{H}_{2} \mathrm{O}$ in nanocrystals. Force cons and type of bonding possess impact on $\mathrm{C}_{11}$ and $\mathrm{C}_{12}$ "stiffness const". Intensive surge of $\mathrm{C}_{11}$ and $\mathrm{C}_{12}$ assigned to strong atomic bonding between $\mathrm{Fe}^{3+}, \mathrm{Mn}^{2+}$ and $\mathrm{Cu}^{2+}$ cations.

Young's modulus E, bulk modulus $\mathrm{K}$ and modulus of rigidity $\mathrm{G}$ are concluded via $[12,24,25]$ :

Young's modulus $\quad E=\frac{\left(C_{11}-C_{12}\right)\left(C_{11}+2 C_{12}\right)}{\left(C_{11}+C_{12}\right)}$

Rigidity modulus $\quad G=\frac{E}{2(\sigma+1)}$

Bulk modulus $\quad K=\frac{1}{3}\left(C_{11}+2 C_{12}\right)$

Table 4 clarifies that the 3-moduli: E, K and G irregularly change versus $\mathrm{x}$. Their declining can refer to the diminishing of inter-atomic bonding in nanocrystals and 
the increase of repulsion between $\mathrm{Fe}^{3+}, \mathrm{Mn}^{2+}$ and $\mathrm{Cu}^{2+}$ cations in synchrony with $x$. The fast decline may be assigned to the permutation process [24,25].

Estimation for longitudinal elastic wave velocity $\left(\mathrm{V}_{\mathrm{L}}\right)$, shear wave velocity $\left(\mathrm{V}_{\mathrm{S}}\right)$ and mean wave velocity $\left(\mathrm{V}_{\mathrm{m}}\right)$ are concluded via the formulations [24,25]:

Longitudinal velocity: $\quad \mathrm{V}_{\mathrm{L}}=\left(\frac{C_{11}}{D_{x}}\right)^{\frac{1}{2}} \quad$ Shear velocity: $\quad \mathrm{V}_{\mathrm{S}}=\left(\frac{G_{0}}{D_{x}}\right)^{\frac{1}{2}}$ The mean wave velocity $\mathrm{V}_{\mathrm{m}}$ can be deduced using the relation; $\frac{3}{V_{m}^{3}}=\frac{1}{V_{L}^{3}}+\frac{2}{V_{S}^{3}}$

, $\mathrm{G}_{\mathrm{o}}$ is rigidity modulus with zero pore fraction.

Table 4 evidences variation of $\mathrm{V}_{\mathrm{L}}, \mathrm{V}_{\mathrm{S}}$ and $\mathrm{V}_{\mathrm{m}}$ versus $x$. Explicitly, $\mathrm{V}_{\mathrm{L}}, \mathrm{V}_{\mathrm{S}}$ and $\mathrm{V}_{\mathrm{m}}$ irregularly change with $x$. It is obvious that, dependency of density $\mathrm{D}_{x}$ on both elastic moduli and wave velocities robustly impressing their estimation. This reflects the variation of crystal structure and proves that wave velocities are strongly correlated with nanocrystals density [7,24,25].

Table 4: Elastic moduli; Young's modulus E, modulus of rigidity G and bulk modulus $\mathrm{K}$, longitudinal elastic wave velocity $\left(\mathrm{V}_{\mathrm{L}}\right)$, shear wave velocity $\left(\mathrm{V}_{\mathrm{S}}\right)$ and mean wave velocity $\left(\mathrm{V}_{\mathrm{m}}\right)$, error $= \pm 0.02$.

\begin{tabular}{|c|c|c|c|c|c|c|}
\hline \hline $\boldsymbol{x}$ & $\mathbf{E}$ & $\mathbf{G}$ & $\mathbf{K}$ & $\mathbf{V}_{\mathbf{L}}$ & $\mathbf{V}_{\mathbf{S}}$ & $\mathbf{V}_{\mathbf{m}}$ \\
\hline 0 & 328.48 & 136.55 & 184.2 & 8.01 & 5.36 & 5.856 \\
\hline 0.25 & 342.56 & 141.14 & 199.3 & 8.26 & 5.49 & 6.008 \\
\hline 0.5 & 321.75 & 130.64 & 199.7 & 8.15 & 5.35 & 5.858 \\
\hline 0.75 & 328.89 & 132.15 & 214.5 & 8.37 & 5.43 & 5.954 \\
\hline 1 & 322.68 & 127.87 & 225.7 & 8.46 & 5.39 & 5.930 \\
\hline \hline
\end{tabular}

\subsection{Thermal Analysis (DTA/TGA)}


Differential thermic analysis (DTA) and thermo-gravimetric analysis (TGA) for $\mathrm{Mn}_{x} \mathrm{Cu}_{1-x} \mathrm{La}_{0.12} \mathrm{Fe}_{1.88} \mathrm{O}_{4},(x=0,0.25,0.5,0.75$ and 1) nanocrystals were performed from room temperature up to $1000{ }^{\circ} \mathrm{C}$ in $\mathrm{N}_{2}$-atmosphere at a heat rate of $15{ }^{\circ} \mathrm{C} \mathrm{min}^{-1}$. Fig. 5 and 6 illustrates DTA/TGA diagrams [26-28]. Fig. 6 illuminates registered TGA diagrams that clarify 3- distinguished portions of mass loss. (1) First portion, from RT up to $380^{\circ} \mathrm{C}$. Obviously, diagrams present a gradual declining of mass with surging temp. Piecemeal mass loss prior to $100{ }^{\circ} \mathrm{C}$ is imputed to the volatized residual $\mathrm{H} 2 \mathrm{O}$ [29], which is affirmed by endothermal transform between ambient temp and $100{ }^{\circ} \mathrm{C}$ in DTA diagrams ( Fig. 5 ) [30].

First exothermal summit appears in DTA at $\sim 95{ }^{\circ} \mathrm{C}$ and also first endothermal summit protrude at $\sim 40{ }^{\circ} \mathrm{C}$, where mass loss ranges $2-8 \%$ mass, imputing to the volatilizing of $\mathrm{H} 2 \mathrm{O}[31,32]$. Earlier portion illuminated other exothermal summit also at $\sim 100{ }^{\circ} \mathrm{C}$, giving mass losses $\sim 8 \%$ mass, imputing to the outstanding volatilizing and dissociation of other residual $\mathrm{H}_{2} \mathrm{O}$ [31,32]. Regarding this demeanour of previous portions they assigned to the dehydrating of Nano-powders. Volatilizing condition is achieved at $\sim 344{ }^{\circ} \mathrm{C}$ [31]. Second portion appeared in temp range from 150 to $350{ }^{\circ} \mathrm{C}$ related to the decomposition and forming of metal hydroxide, giving mass loss $14-17 \%$ mass [26,31]. Third portion arises from transforming of metal hydroxide into their analogous metal oxide appears in DTA and TGA as endothermal mass loss protruded around 688 ${ }^{\circ} \mathrm{C}$ producing mass loss $\sim 20 \%$ mass. $\mathrm{Fe}_{2} \mathrm{O}_{3}$ is derived from $\mathrm{Fe}_{2}(\mathrm{OH})_{3}$ and $\mathrm{Mn}_{3} \mathrm{O}_{4}$ is from $\mathrm{Mn}(\mathrm{OH})_{3}$ at $\sim 688{ }^{\circ} \mathrm{C}$ [26,31]. Fourth mass loss, giving endothermal summit and exothermal summit protruded around $920{ }^{\circ} \mathrm{C}$ imputing to decomposing of metal oxides and nucleation of Nano-spinel mono-phase, giving minimal mass loss $~ 22 \%$ mass [31]. DTA/TGA diagrams illuminate a broad exothermal summit up to $\sim 880{ }^{\circ} \mathrm{C}$ which is imputing to the forming and advancement of crystallization of nanocrystals; net mass loss of nanocrystals heated from ambient temperature up to $1000{ }^{\circ} \mathrm{C}$ ranges in between $2-22 \%$ mass, where the maximal mass loss clarified at $100{ }^{\circ} \mathrm{C}$ and $688{ }^{\circ} \mathrm{C}$. Obviously, DTA 
summits are corresponding to mass loss portions clarified from the TGA diagrams [26,31,32].
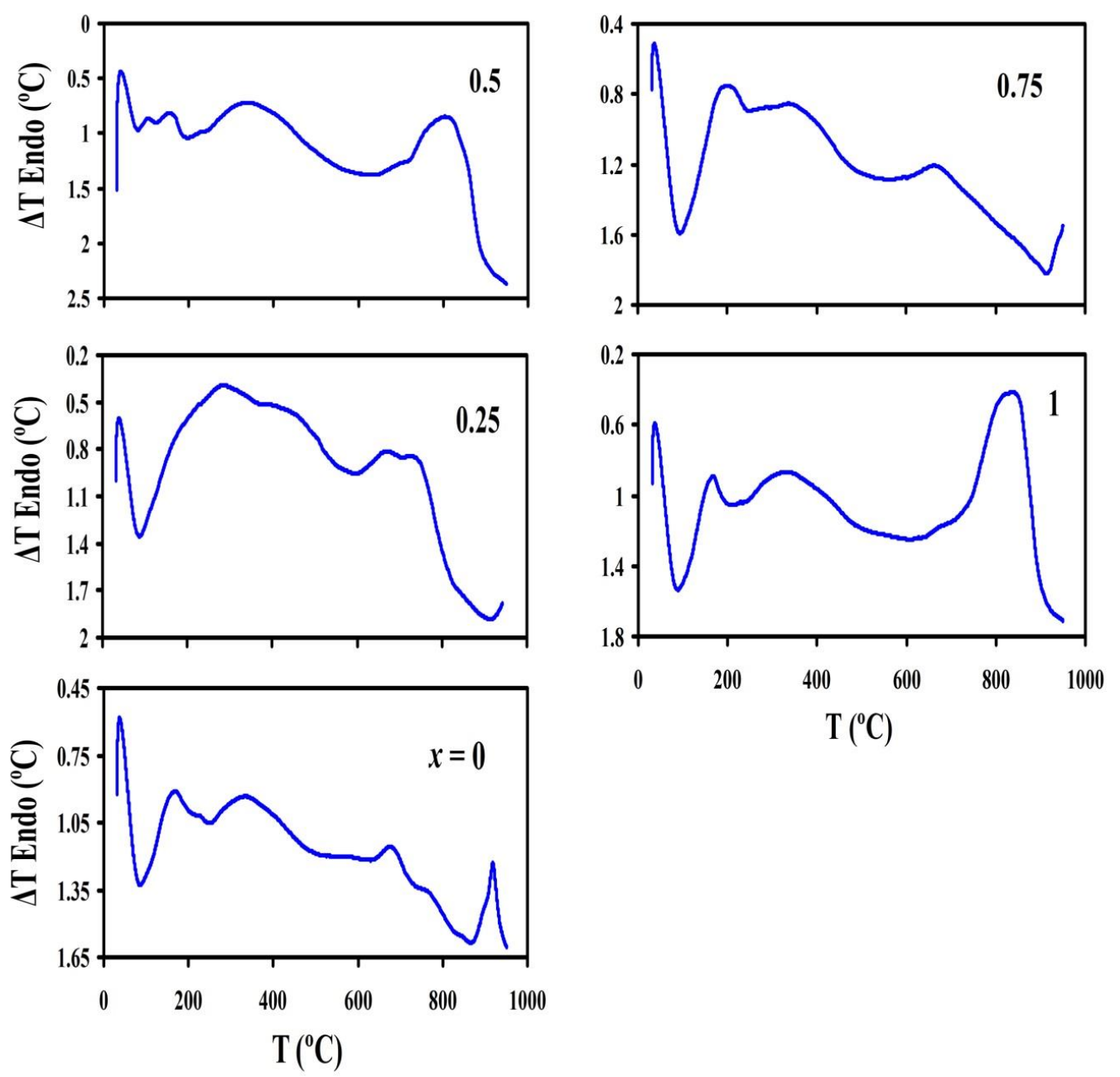

Fig. 5 DTA curves for $\mathrm{Mn}_{x} \mathrm{Cu}_{1-x} \mathrm{La}_{0.12} \mathrm{Fe}_{1.88} \mathrm{O}_{4},(x=0,0.25,0.5,0.75$ and 1) nanocrystals. 

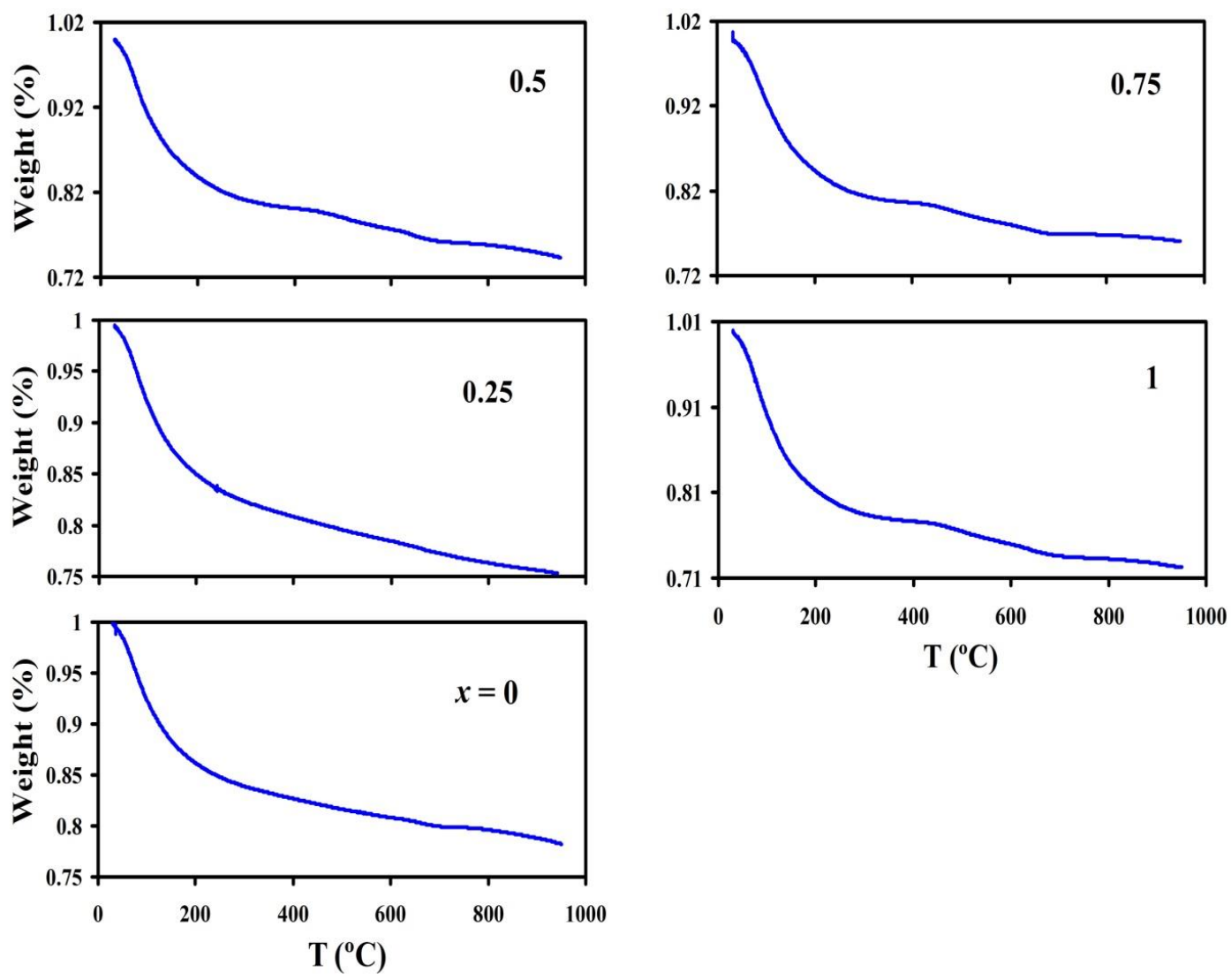

Fig. 6 TGA curves for $\mathrm{Mn}_{x} \mathrm{Cu}_{1-x} \mathrm{La}_{0.12} \mathrm{Fe}_{1.88} \mathrm{O}_{4},(x=0,0.25,0.5,0.75$ and 1$)$ nanocrystals.

\subsection{Electrochemical Performance}

Electrochemical performance of $\mathbf{M n L a}_{0.12} \mathbf{F e}_{1.88} \mathbf{O}_{4}$ Nano-spinel was scrutinized via Cyclic Voltametry (CV) and Galvano-static charging/discharging which was examined in $1 \mathrm{M} \mathrm{KOH}$ electrolytes at ambient temp. CV diagrams of these Nanospinels electrodes were scrutinized at various scan rates $(5-100 \mathrm{mV} / \mathrm{s})$ in potential range of -0.58 to $0.58 \mathrm{~V}$ ( Fig. 7-a ). $\mathbf{M n L a}_{0.12} \mathbf{F e}_{1.88} \mathbf{O}_{\mathbf{4}}$ Nano-spinel electrode demonstrated larger $\mathrm{CV}$ diagram area, illuminating their superiors electrochemical performance. Area of circumfluent CV diagrams surge with scan rate. The rectangular $\mathrm{CV}$ curve for these Nano-spinels electrode at lower scanning rates illuminates the exemplary double-layer capacitive demeanours. CV curves 
emphasized redox summits when scan rate was surged from lowest to biggest estimation. This illuminates that redox reactions on electrode surface were fast and reversible. Galvano-static charging/discharging mensuration of these Nanospinels electrode is demonstrated in Fig. 7-b. At lower current densities, sharp droping can be observed in the Galvano-static charging/discharging diagram indicating a lower internally resistance. Fig. 7-b, as well as demonstrated fine reversibility. Specified capacitive demeanour of $\mathbf{M n L a}_{0.12} \mathbf{F e}_{1.88} \mathbf{O}_{4}$ Nano-spinel electrode was concluded from CV diagrams as illuminated in Fig. 7-e. Fig. 7-e illustrate that estimation of specified capacitance slightly declines with surge of scan rate. Long cycling stability is a decisive demand to super-capacitive electrode for implementations. Cyclic stability of these Nano-spinel electrode materials has been scrutinized from 1000 cyclic voltammetry test at a higher scan rate of $50 \mathrm{mV} / \mathrm{s}$ as illuminated in Fig. 7-d. The performance of $\mathbf{M n L a}_{\mathbf{0 . 1 2}} \mathbf{F e}_{\mathbf{1 . 8 8}} \mathbf{O}_{\mathbf{4}}$ Nano-spinel affirms that it is electrode nanomaterials for Super-capacitive implementations and sensing. Electrical demeanour of electrode nanomaterials for SCs implementations can be scrutinized with aid of Electrochemical impedance Spectroscopy (EIS). Fig. 7-c, illuminates Nyquist graphs for these Nano-spinels in the frequency range from $1.0 \mathrm{~Hz}$ to $20 \mathrm{kHz}$. Soln reluctance (Rs) is acquired from the intercept of the real axis $\left(Z^{\prime}\right)$ in the higher frequency portion. Obviously, $\mathrm{MnLa}_{0.12} \mathbf{F e}_{1.88} \mathbf{O}_{\mathbf{4}}$ Nano-spinels retains very low estimation of Rs as $12.9 \Omega$. 

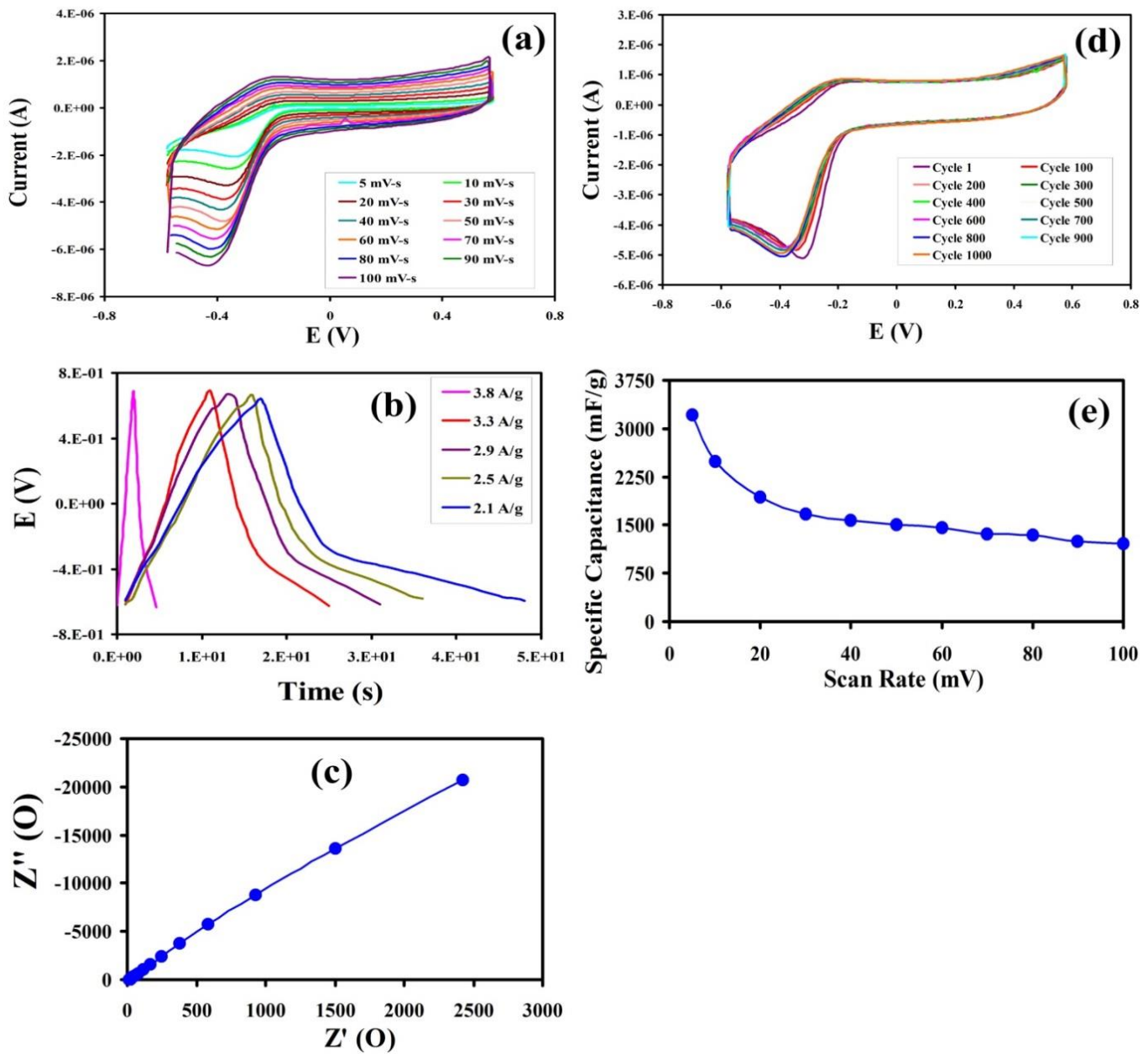

Fig. 7. The electrochemical performance of $\mathrm{MnLa}_{\mathbf{0 . 1 2}} \mathrm{Fe}_{1.88} \mathrm{O}_{\mathbf{4}}$ spinel nanoparticles electrode; (a) CV curves at different scan rates, (b) galvanostatic charge/ discharge curve, (c) Nyquist plot of $\mathbf{M n L} \mathbf{a}_{\mathbf{0 . 1 2}} \mathbf{F e}_{\mathbf{1 . 8 8}} \mathbf{O}_{\mathbf{4}}$ spinel nanoparticles, (d) Stability curves, (e) the specific capacitance as a function of scan rate.

\section{Conclusion}

$\mathrm{Mn}_{x} \mathrm{Cu}_{1-x} \mathrm{La}_{0.12} \mathrm{Fe}_{1.88} \mathrm{O}_{4},(x=0,0.25,0.5,0.75$ and 1) Nano-spinels have been fabricated via co-precipitation methodology and scrutinized via XRD, FTIR and DTA/TGA techniques. XRD plots emphasized the complete evolution of the monocular-phase Nano-spinel for all the scrutinized Nano-powders. All parameters illustrated reliance on $\mathrm{Mn}^{2+}$ content $x$. From DTA/TGA curves the net 
weight loss approaches $\approx 22 \%$. Cyclic voltammetry and Galvano-static charging/discharging scrutiny were adjusted to scrutinize the electrochemical merits of $\mathbf{M n L a}_{0.12} \mathbf{F e}_{1.88} \mathbf{O}_{4}$ spinel nanoparticles in $1.0 \mathrm{M} \mathrm{KOH}$ electrolyte solution. $\mathbf{M n L a}_{0.12} \mathbf{F e}_{\mathbf{1 . 8 8}} \mathrm{O}_{4}$ Nano-spinel demonstrated specific capacitance of $1500 \mathrm{mF} / \mathrm{g}$ at $50 \mathrm{mV} / \mathrm{s}$. The scrutiny illuminates a marvellous implementation of $\mathrm{MnLa}_{0.12} \mathrm{Fe}_{1.88} \mathrm{O}_{4}$ spinel nanoparticles as electrode materials for energy storage. $\mathrm{MnLa}_{0.12} \mathrm{Fe}_{1.88} \mathrm{O}_{4}$ spinel nanoparticles retains low value of solution reluctance (Rs) as $12.9 \Omega$.

\section{References}

[1] Masaru Tada, Takashi Kanemaru, Takeshi Hara, Takashi Nakagawa, Hiroshi Handa, Masanori Abe, Synthesis of hollow ferrite nanospheres for biomedical applications, J. Magn.. Magn. Mat., 321 (2009) 1414-1416, doi:10.1016/j.jmmm.2009.02.053.

[2] M.A. Amer, T.M. Meaz, S.S. Attalah, A.I. Ghoneim, Structural phase transformation of as-prepared $\mathrm{Mg}-\mathrm{Mn}$ nanoferrites by annealing temperature, Mat. Char., 110 (2015) 197-207, http://dx.doi.org/10.1016/j.matchar.2015.10.032.

[3] A I Ghoneim, TM Meaz, Structural and ferri-magnetic features of the nanocrystalline $\mathrm{Mn}_{0.5} \mathrm{Cd}_{\mathrm{x}} \mathrm{Sr}_{0.5-\mathrm{x}} \mathrm{Fe}_{2} \mathrm{O}_{4}$ nanoparticles, IOP Conf. Series: Journal of Physics: Conf. Series 1253 (2019) 012019, doi:10.1088/17426596/1253/1/012019.

[4] M.A. Amer, T.M. Meaz, S.S. Attalah, A.I. Ghoneim, Structural and magnetic characterization of the $\mathrm{Mg}_{0.2-x} \mathrm{Sr}_{x} \mathrm{Mn}_{0.8} \mathrm{Fe}_{2} \mathrm{O}_{4}$ nanoparticles, J. Magn. Magn. Mat., $363 \quad$ (2014) 60-65, http://dx.doi.org/10.1016/j.jmmm.2014.03.067.

[5] SS Thakur, A Pathania, P Thakur, A Thakur, J-H Hsu, Improved structural, electrical and magnetic properties of $\mathrm{Mn}-\mathrm{Zn}-\mathrm{Cd}$ nanoferrites, $\underline{\text { Ceram. }}$ 
Intern.,

$\underline{41}(2015)$

$5072-5078$.

http://dx.doi.org/10.1016/j.ceramint.2014.12.077 .

[6] KK Bamzai, G Kour, B Kaur, M Arora, RP Pant, Infrared spectroscopic and electron paramagnetic resonance studies on Dy substituted magnesium ferrite, J. Magn. Magn. Mater., 345 (2013) 255-260. http://dx.doi.org/10.1016/j.jmmm.2013.07.002.

[7] KB Modi, SJ Shah, NB Pujara, TK Pathak, NH Vasoya, IG Jhala, Infrared spectral evolution, elastic, optical and thermodynamic properties study on mechanically milled $\mathrm{Ni}_{0.5} \mathrm{Zn}_{0.5} \mathrm{Fe}_{2} \mathrm{O}_{4}$ spinel ferrite, J. Mol. Str., 1049 (2013) 250-262. http://dx.doi.org/10.1016/j.molstruc.2013.06.051

[8] Rajesh Kumar, Sally M. Youssry, Kyaw Zay Ya, Wai Kian Tan, Go Kawamura, Atsunori Matsuda, Microwave-assisted synthesis of Mn3O4Fe2O3/Fe3O4@rGO ternary hybrids and electrochemical performance for supercapacitor electrode, Diamond \& Related Materials 101 (2020) 107622, https://doi.org/10.1016/j.diamond.2019.107622

[9] M Rahimi, M Eshraghi, P Kameli, Structural and magnetic characterizations of Cd substituted nickel ferrite nanoparticles, Ceram. Intern., 40 (2014) 15569-15575. http://dx.doi.org/10.1016/j.ceramint.2014.07.033.

[10] A I Ghoneim, T M Meaz, H A Aboelkhir, Structural, thermal and ferrimagnetic studies of the as-fabricated $\mathrm{La}^{3+}$-doped Co-nano-spinels, IOP Conf. Series: Journal of Physics: Conf. Series 1253 (2019) 012020, doi:10.1088/1742-6596/1253/1/012020.

[11] G Dixit, JP Singh, RC Srivastava, HM Agrawal, Magnetic resonance study of $\mathrm{Ce}$ and $\mathrm{Gd}$ doped $\mathrm{NiFe}_{2} \mathrm{O}_{4}$ nanoparticles, J. Magn. Magn. Mater., 324 (2012) 479-483. doi:10.1016/j.jmmm.2011.08.027.

[12] M.A. Amer, T.M. Meaz, S.S. Attalah, A.I. Ghoneim, Annealing effect on structural phase transition of as-synthesized $\mathrm{Mg}_{0.1} \mathrm{Sr}_{0.1} \mathrm{Mn}_{0.8} \mathrm{Fe}_{2} \mathrm{O}_{4}$ nanoparticles, J. Alloys Compds 654 (2016) 45-55, http://dx.doi.org/10.1016/j.jallcom.2015.09.114. 
[13] MA Amer, TM Meaz, SS Attalah, AI Ghoneim, Structural phase transition of as-synthesized $\mathrm{Sr}-\mathrm{Mn}$ nanoferrites by annealing temperature, J. Magn. Magn. Mater., $393 \quad$ (2015) $\quad$ 467-478. http://dx.doi.org/10.1016/j.jmmm.2015.06.013

[14] BD Cullity, Elements of X-ray diffraction, Second Edition, Addison-Wesley Publishing Company, INC, United States of America, Congress catalog No 56-10137, (1978).

[15] V Kumar, Y Ali, RG Sonkawade, AS $\underline{\text { Dhaliwal, (2012) Effect of gamma }}$ irradiation on the properties of plastic bottle sheet, Nucl. Instrum. $\begin{array}{lllllll}\text { Methods Phys. Res. Sec. B, } & 287 & \text { (2012) 10-14. }\end{array}$ http://dx.doi.org/10.1016/j.nimb.2012.07.007

[16] N Lenin, RR Kanna, K Sakthipandi, AS Kumar, Structural, electrical and magnetic properties of $\mathrm{NiLa}_{\mathrm{x}} \mathrm{Fe}_{2-\mathrm{x}} \mathrm{O}_{4}$ Nanoferrites, Mater. Chem. and Phys. $212 \quad$ (2018) 385-393. 212:385-393. DOI: 10.1016/j.matchemphys.2018.03.062

[17] BD Cullity, Introduction to magnetic materials. Addison-Wesley Publishing, Inc., Boston, (1972).

[18] M Hashim, KS Alimuddin, SE Shirsath, RK Kotnala, H Chung, R Kumar, Structural properties and magnetic interactions in $\mathrm{Ni}_{0.5} \mathrm{Mg}_{0.5} \mathrm{Fe}_{2-\mathrm{x}} \mathrm{Cr}_{\mathrm{x}} \mathrm{O}_{4}$ $(0 \leq x \leq 1)$ ferrite nanoparticles, Powder Technology, 229 (2012) 37-44. doi:10.1016/j.powtec.2012.05.054

[19] SA Saafan, TM Meaz, EH El-Ghazzawy, MK El Nimr, MM Ayad, M Bakr, A.C. and D.C. conductivity of NiZn ferrite nanoparticles in wet and dry conditions. J. Magn. Magn. Mater., 322 (2010) 2369-2374. doi:10.1016/j.jmmm.2010.02.039

[20] S Gaba, A Kumar, PS Rana, M Arora, Influence of $\mathrm{La}^{3+}$ ion doping on physical properties of magnesium nanoferrites for microwave absorption application, J. Magn. Magn. Mat., $460 \quad$ (2018) 69-77. https://doi.org/10.1016/j.jmmm.2018.03.035 
[21] M Lakića, L Andjelković, M Šuljagić, P Vulić, M Perić, P Iskrenović, I Krstić, MM Kuraica, AS Nikolić, Optical evidence of magnetic fieldinduced ferrofluid aggregation: Comparison of cobalt ferrite, magnetite, and magnesium ferrite, Optical Mat. 91 (2019) 279-285. https://doi.org/10.1016/j.optmat.2019.03.031

[22] ZI Abdeen, AI Ghoneim, Improving of the Mg-Co nanoferrites efficiency for crude oil adsorption from aqueous solution by blending them with chitosan hydrogel, Env. Sci. Pol. Res (2018). 1-11. https://doi.org/10.1007/s11356-018-3557-y

[23] MA Amer, TM Meaz, SS Attalah, AI Ghoneim, Structural phase transformation of as-prepared $\mathrm{Mg}-\mathrm{Mn}$ nanoferrites by annealing temperature, Mat. Char., 110 (2015) 197-207. http://dx.doi.org/10.1016/j.matchar.2015.10.032

[24] SM Patange, SE Shirsath, KS Lohar, SG Algude, SR Kamble, N Kulkarni, DR Mane, KM Jadhav, Infrared spectral and elastic moduli study of $\mathrm{NiFe}_{2-\mathrm{x}} \mathrm{Cr}_{\mathrm{x}} \mathrm{O}_{4}$ nanocrystalline ferrites. J. Magn. Magn. Mater., 325 (2013) 107-111. http://dx.doi.org/10.1016/j.jmmm.2012.08.022

[25] SM Patange, SE Shirsath, SP Jadhav, VS Hogade, SR Kamble, KM Jadhav, Elastic properties of nanocrystalline aluminium substituted nickel ferrites prepared by co-precipitation method. J. Mol. Str., 1038 (2013) 40-44. http://dx.doi.org/10.1016/j.molstruc.2012.12.053

[26] K Kumar, A Loganathan, The structural, electrical and magnetic properties of $\mathrm{Co} 2+$ content dependent $\mathrm{Mg}-\mathrm{Sr}$ nanoferrite for electromagnetic induction. Materials Science and Engineering B 224 (2017) 4855.https://doi.org/10.1016/j.mseb.2017.07.007

[27] D Gherca, N Cornei, O Mentré, H Kabbour, S Daviero-Minaud, A Pui, In situ surface treatment of nanocrystalline $\mathrm{MFe} 2 \mathrm{O} 4(\mathrm{M}=\mathrm{Co}, \mathrm{Mg}, \mathrm{Mn}, \mathrm{Ni})$ spinel ferrites using linseed oil. Applied Surface Science 287 (2013) 490498. https://doi.org/10.1016/j.apsusc.2013.10.018 
[28] AZ Noah, MA El Semary, AM Youssef, MA El-Safty, Enhancement of yield point at high pressure high temperature wells by using polymer nanocomposites based on $\mathrm{ZnO} \& \mathrm{CaCO} 3$ nanoparticles. Egyptian Journal of PetroleumVolume 26, Issue 1, (2017) 33-40. https://doi.org/10.1016/j.ejpe.2016.03.002

[29] R. Gimenes, M.R. Baldissera, M.R.A. da Silva, C.A. DA Silveira, D.A.W. Soares, L. A. Perazolli, M.R. da Silva, M.A. Zaghete, Ceram. Int. 38 (2012) 741 .

[30] R.A. Khan, S. Mir, A.M. Khan, B.I smail, AbdurRahman Khan, Ceram. Int. 40 (2014) 11205.

[31] AA Ati, Z Othaman, A Samavati, FY Doust, Structural and magnetic properties of $\mathrm{Co}-\mathrm{Al}$ substituted $\mathrm{Ni}$ ferrites synthesized by co-precipitation method. Journal of Molecular Structure 1058 (2014) 136-141. https://doi.org/10.1016/j.molstruc.2013.10.042

[32] PP Hankare, VT Vader, NM Patil, SD Jadhav, UB Sankpal, MR Kadam, BK Chougule, NS Gajbhiye, Synthesis, characterization and studies on magnetic and electrical properties of $\mathrm{Mg}$ ferrite with $\mathrm{Cr}$ substitution. Materials Chemistry and Physics 113 (2009) 233-238. https://doi.org/10.1016/j.matchemphys.2008.07.066 